\title{
ANALISIS TIME SERIES MODEL ARMA UNTUK MEMPREDIKSI JUMLAH SANTRI PP SALAFIYAH SYAFI'IYAH SUKOREJO 2017-2021
}

\author{
Oleh:
}

\author{
Maswar
}

Fakultas Ekonomi dan Bisnis Islam IAI Ibrahimy Situbondo

Email: maswar.febi@gmail.com

\begin{abstract}
:
Time series analysis aims to forcasttime seriesdata in some future period based on the data in the past. The main aim of this research is to forcast the number of the new students of Salafiyah Syafi'iyahSukorejo Boarding School in Situbondo using Auto Regressive Moving Average (ARMA). This research uses annual data from 2005 until 2016. It is discusses the steps of timeseriesanlysis using the Box-Jenkinsmethod. That method comprises of several stages, they are model identification stage, parameter estimation stage, diagnostic checking and forecasting stage. Model identification stage is done by finding the model $(p, q)$ that are considered as the most appropriate by looking at the plot of ACF and PACF of the correlogram. Parameter estimation stage is done by estimating model parameters.Whereas, Diagnostic testing and forecasting stage is done by seeing if residual estimation results is already have the quality of white noise.After the appropriate model has been identified, the next step is to use this model for forecasting. The results of this study shows that the ARMA model (2.0) provide the better forecasting results with squared the smallest value of SSR, AICand SIC.
\end{abstract}

Key Words: Forecasting, Time Series, Data, ARMA, SSR, AIC, SIC

\section{A. Pendahuluan}

Dalam menganalisis suatu fenomena sekitar tentu tidak selalu menggunakan metode hubungan sebab akibat, seperti yang biasa digunakan dalam analisis parametris, yaitu metode regresi korelasi. Pada metode regresi korelasi, peneliti menggunakan dua variabel atau lebih dan mencari pengaruh satu atau beberapa variabel independen terhadap variabel dependennya. Dalam dunia ekonomi, dikenal juga data runtut waktu (time series), yang diduga memiliki karakteristik tertentu, sehingga nilainya berfluktuasi. Sebagai contoh adalah harga saham suatu perusahaan.

Ada beberapa pengamat yang berpendapat bahwa harga saham 
pada hari ini, sangat dipengaruhi oleh harga saham pada hari kemarin, atau hari-hari sebelumnya. Demikian juga harga saham hari ini akan mempengaruhi harga saham besok atau harga saham berikutnya. Data seperti ini, yaitu data yang terdiri atas suatu objek dan terdiri atas beberapa periode waktu, disebut dengan data runtut waktu (time series). Analisis terhadapat data runtut waktu disebut dengan analisis runtut waktu atau time series analysis. ${ }^{1}$

Menilik pada berbagai fenomena yang ada di Pondok Pesantren Salafiyah Syafi'iyah Sukorejo Situbondo, terdapat hal menarik yang menggugah pemikiran untuk dianalisis, lebih-lebih berkaitan dengan fenomena yang datanya berupa data runtut waktu (time series data). Adapun hal tersebut ialah data jumlah santri baru (putra dan putri) setiap tahun, yang masuk sebagai santri Pondok Pesantren Salafiyah Syafi'iyah Sukorejo Situbondo dari tahun 2005 hingga tahun 2016. Penentuan interval data tersebut, didasarkan pada data valid yang diperoleh dari kabag informasi kantor pusat pondok. Meskipun sudah dimulai sejak 6 tahun pasca berdirinya Pondok Pesantren Salafiyah Syafi'iyah Sukorejo, yaitu tepatnya pada tahun $1914^{2}$, santri baru sudah mulai berdatangan ke pesantren tersebut untuk menyantri, namun baru pada tahun 2005 data santri baru setiap tahunnya ter-cover dengan baik.

Menilik pada peran penting suatu pendekatan ilmiah sebagai langkah berpikir realistis, maka penelitian ini mencoba untuk meramalkan jumlah santri baru Pondok Pesantren Salafiyah Syafi'iyah Sukorejo dalam 5 tahun ke depan berdasarkan data santri baru periode tahun-tahun sebelumnya, yaitu periode tahun 2015-2016. Peramalan jumlah santri baru yang bersifat musiman serta kejadiannya berulang ini, akan dilakukan menggunakan model ARMA $(p, q)$.

\section{B. Metode Penelitian}

Jenis penelitian ini adalah deskriptif kuantitatif. Pendekatan deskriptif adalah penyajian dan penyusunan data ke dalam gambar atau grafik. Sedangkan, pendekatan kuantitatif adalah melakukan analisis terhadap data nominal yakni data runtut waktu (time series data) berkait jumlah santri baru Pondok Pesantren Salafiyah Syafi'iyah Sukorejo Situbondo dari tahun 2005 sampai tahun 2016 dengan menggunakan

\footnotetext{
${ }^{1}$ Wahyu Winarno.W, Analisis Ekonomitrika dan Statistika dengan Eviews, (Yogyakarta: UPP STIM YKPN, 2015), hlm. 71.

${ }^{2}$ Choirul Anam (ed.), KHR. As'ad Syamsul Arifin: Riwayat Hidup dan Perjuangannya, (Situbondo : Pondok Pesantren Salafiyah Safiiyah Sukorejo, 1994), hlm. 45.

$60 \mid$ JURNAL LISAN AL-HAL
} 
program EVIEWS 8.1.

Adapun jenis data dalam penelitian ini adalah data sekunder yang diperoleh dari kepala bagian (Kabag) informasi kantor pusat Pondok Pesantren Salafiyah Syafi'iyah Sukorejo Situbondo. Sedangkan, metode analisis data yang digunakan dalam penelitian ini adalah metode BoxJenkins. Metode Box dan Jenkins, yang dikenal dengan model Autoregressive integrated moving avarage(ARIMA)meliputi beberapa tahapan, yaitu (1) tahap identifikasi model, (2) tahap estimasi parameter model, (3) tahap uji diagnosis, dan (4) tahap peramalan (forcasting). Tahap identifikasi model dilakukan dengan cara mencari model (nilai p, dan q) yang dianggap paling sesuai dengan melihat plot ACF dan PACF dari correlogram. Tahap estimasi parameter model dilakukan dengan cara menaksir parameter-parameter model. Sedangkan, tahap uji diagnosis dilakukan dengan cara melihat apakah residual hasil estimasi sudah bersifat white noise. Residual yang white noisemenunjukkan suatu model sudah tepat dengan datanya. Setelah model yang sesuai sudah teridentifikasi, maka langkah selanjutnya ialah menggunakan model tersebut untuk melakukan peramalan (forcasting) ${ }^{3}$.

\section{Proses White Noise}

Data yang white noise akan diperoleh manakala data bersifat stokastik (random). Proses whitenoise merupakan proses yang penting karena merupakan faktor pembangun bagi proses data runtun waktu lainnya. Hal demikian dapat ditunjukkan bahwa data white nose adalah bersifat stasioner $\left(X_{t} \sim W N\left(0, \sigma^{2}\right)\right.$.

\section{Proses Autoregressive (AR)}

Autoregressive adalah data sekarang dipengaruhi oleh data sebelumnya. Model umum runtun waktu AR adalah:

$X_{t}=\beta_{0}+\beta_{1} X_{t-1}+\beta_{2} X_{t-2}+\cdots+\beta_{p} X_{t-p}+e_{t}$

Keterangan:

$X_{t}=$ data pada periode ke-t

$\beta_{p}=$ parameter autoregressive pada periode ke-t

$X_{t-1} \ldots X_{t-p}=$ variabel data yang menunjukkan data runtun waktu yang

${ }^{3}$ Wahyu Winarno.W, Analisis Ekonomitrika dan Statistika dengan Eviews, (Yogyakarta: UPP STIM YKPN, 2015), hlm. 7.23. Bandingkan dengan Agus Widarjono, 2016. Ekonomitrika: Pengantar dan Aplikasinya, (Yogyakarta : UPP STIM YKPN, 2016), hlm. 270. 
bersangkutan

$e_{t}=$ nilai residual pada saat $\mathrm{t}$

\section{Proses Moving Average(MA)}

Moving average adalah proses stokastik berupa model time series statistik dengan karakteristik nilai residual data sekarang dipengaruhi oleh nilai residual data sebelumnya. Model umum runtun waktu MA adalah:

$X_{t}=e_{t}-\alpha_{1} e_{t-1}-\alpha_{2} e_{t-2}-\cdots-\alpha_{q} e_{t-q}$

Keterangan:

$X_{t}=$ data pada periode ke-t

$\alpha_{q}=$ parameter moving average pada periode ke- $t$

$e_{t-1} \ldots e_{t-q}=$ variabel residual yang menunjukkan data runtun waktu yang bersangkutan.

$e_{t}=$ nilai residual pada saat $\mathrm{t}$

\section{Proses Autoregressive dan Moving Average (ARMA)}

Bila pada proses autoregressive(AR) maupun pada proses moving average (MA) suatu model bekerja secara parsial, maka pada proses ARMA bekerja secara simultan. Autoregressive moving average(ARMA) merupakan gabungan dari data sekarang dan nilai residual sekarang secara bersama-sama dipengaruhi oleh data dan nilai residual sebelumnya. Model umum runtun waktu ARMA adalah:

$$
\begin{gathered}
X_{t}=\beta_{0}+\beta_{1} X_{t-1}+\beta_{2} X_{t-2}+\cdots+\beta_{p} X_{t-p}+e_{t}-\alpha_{1} e_{t-1}-\alpha_{2} e_{t-2}-\cdots \\
-\alpha_{q} e_{t-q}
\end{gathered}
$$

Keterangan:

$X_{t}=$ data pada periode ke-t

$\beta_{p}=$ parameter autoregressive pada periode ke-t

$\alpha_{q}=$ parameter moving average pada periode ke- $t$

$e_{t}=$ nilai residual pada saat $\mathrm{t}$

Dalam banyak kasus alisis data runtun waktu, proses AR maupun MA cukup memadai, namun kadangkala memiliki keterbatasan tertentu sehingga ditemui kasus identifikasi model menghasilkan kesimpulan bahwa data mengikuti proses AR sekaligus MA atau bisa saja sebagian AR dan sebagian lainnya MA. Dalam kasus seperti ini data dikatakan $62 \mid$ JURNAL LISAN AL-HAL 
mengikuti proses ARMA. Model ARMA kerap kali disebut dengan model ARIMA (p,d,q) tanpa didifferensi, artinya model Autoregressive integrated moving average $(p, d, q)$ memiliki nilai $d=0$.

Adapun langkah-langkah analisis time series menggunakan model ARMAatau yang sering dikenal dengan metode Box-Jenkins sebagai berikut:

\section{Mengidentifikasi Model}

Hal pertama yang harus diperhatikan adalah bahwa kebanyakan data runtun waktu (time series data) bersifat non stasioner. Sifat kestasioneran data menjadi syarat pertama untuk meodel ARIMA. Akan tetapi, karena model yang akan digunakan ialah model ARMA, maka data diasumsikan sudah stasioner pada level 0 atau tanpa dilakukan diffrensi $(d=0)$ terhadap data tersebut.

Karena data sudah diasumsikan stasioner, maka selanjutnya dilakukan identifikasi orde AR dan MA yang sesuai dengan menggunakan correlogram (plot ACF dan PACF). PACF pada lag ke-k menggambarkan korelasi antara $X_{t+k}$ dengan $X_{t}$ setelah dipendensi linear dari variabel $X_{t+1} \ldots X_{t+k-1}$.

Selanjutnya, jika ACF meluruh secara eksponensial dan PACF signifikan pada lag $\mathrm{p}$ maka proses tersebut adalah proses AR (p). Sebaliknya, jika PACF meluruh secara eksponensial dan ACF signifikan pada lag q maka proses tersebut adalah proses MA (q).

AR (p) merupakan proses stokastik berupa model time series stasioner dengan karakteristik data periode sekarang dipengaruhi oleh karakteristik data pada periode sebelumnya. MA (q) merupakan proses stokastik berupa model runtun waktu stasioner dengan karakteristik residual data periode sekarang dipengaruhi oleh karakteristik nilai residual data pada periode sebelumnya. Sedangkan, ARMA $(\mathrm{p}, \mathrm{q})$ merupakan proses stokastik berupa model runtun waktu stasioner dengan karakteristik data dan residual data periode sekarang dipengaruhi oleh karakteristik residual data dan nilai dresiduad data pada periode sebelumnya.

\section{Mengestimasi Parameter Model}

Setelah identifikasi menghasilkan suatu model semnetara, maka dilanjutkan pada tahap berikutnya yaitu melakukan estimasi terhadap 
parameter-parameter dalam model tersebut. Estimasi parameter merupakan perhitungan yang dilakukan untuk mendapatkan nilai parameter suatu model ARMA $(\mathrm{p}, \mathrm{q})$.

\section{Menguji Diagnosis Model}

Setelah melakukan estimasi parameter model atau melakukan penaksiran nilai-nilai paramter model ARMA (p,q) yang ditetapkan sementra, selanjutnya perlu dilakukan pemeriksaan diagnosis (diagnosacheking) untuk membuktikan bahwa model tersebut memadai (valid). Dalam pemeriksaan diagnosa ini, dilakukan uji asumsi-asumsi pemodelan, antara lain:

Uji Normalitas residual

Uji normalitas residual dilakukan untuk mengetahui kenormalan nilai residual data. Suatu model data diakatakn baik apabila residual data berdistribusi normal. Normalitas residual terjadi apabila histogram residual mempunyai kecenderungan membentuk pola lonceng. Selain itu, kenormalan residual data dalam program eviews 8.1 dapat diketahui melalui uji hipotesis Jargue Berra (JB). Jika nilai JB lebih kecil dari nilaichisquare dengan derajat bebas tertentu, maka residual data berdistribusi normal atau jika nilai probabilitas JB lebih dari taraf signifikasitertentu yang digunakan (yakni alpha 0,05), maka residual data berdistribusi normal.

\section{Uji Non-Autokorelasi}

Uji Autokorelasi dilakukan untuk mengetahu apakah residual data mengandung autokeralasi atau tidak. Hal ini dapat dilihat melalui correlogram of residuals. Jika correlogram tersebut menunjukkan adanya plot ACF dan PACF yang signifikan pada lag-lag awal, maka residual mengandung autokorelasi. Jika sebaliknya, maka residual tidak mengandung autokorelasi. Selain itu, pengambilan keputusan juga bisa dilakukan dengan cara melihat nilai probabilitas dari $Q$-statistics. Jika nilai probabilitas $Q$-statistics lebih dari nilai 0,05, maka dapat disimpulkan bahwa varians residual data tidak mengandung autokorelasi.

Uji Homoskedastisitas Residual

Uji ini dilakukan dengan tujuan untuk mengetahui apakah data mengandung heteroskedastisitas atau tidak (varians residual homogen atau tidak). Hal ini dapat diketahui melalui correlogramof residual squard. Jika correlogram tersebut menunjukkan adanya plot ACF dan PACF yang signifikan pada lag-lag pertama maka varians residual tidak konstan. Jika sebaliknya maka varians residul konstan. Selain itu dapat juga diketahui melalui metode White, SpearmanBrown, Glejtser,dll. Pada metode White,

$64 \mid$ JURNAL LISAN AL-HAL 
jika nilai chi-square hitung lebih besar dari dari nilai chi-square gambar dengan derajat bebas $=\mathrm{m}-1$, maka data bersifat heteroskedastisitas. Selain itu, pengambilan keputusan juga bisa dilakukan dengan cara melihat nilai probabilitas dari chi-square (pada $o b s^{*} R$-Squared). Jika nilai probabilitas chi-square lebih dari nilai 0,05 , maka dapat disimpulkan bahwa varians residual data bersifat homoge (homoskedastisitas), atau tidak bersifat heteroskedastisistas.

Dalam analisis time series data, mungkin ada beberapa jenis model yang sesuai untuk menunjukkan data. Alat untuk mengidentifikasi model terbaik ialah nilai AIC dan SIC. Akaike's Information Criterion (AIC) merupakan suatu metode identifikasi model terbaik yang pertama kali diperkenalkan oleh Akaike. Suatu model dikatakn terbaik jika memiliki nilai AIC terkecil dibandingkan dengan nilai AIC yang lainnya. Sedangkan, Schwartz Information Criterion(SIC)merupakan suatu metode untuk mengidentifikasi model terbaik yang pertama kali diperkenalkan oleh Schwartz. Metode ini dikembangkan dengan basis teori Schwartz. Suatu model dikatakan terbaik bila mempunyai nilai SIC terkecil dibandingkan dengan nilai SIC pada model lainnya.

\section{Melakukan Peramalan/Prediksi}

Langkah terakhir pada model ARMA ialah melakukan peramalan nilai atau data pada periode selanjutnya dengan menggunakan model terbaik. Jika data semula sudah melalui transformasi, maka peramalan yang dilakukan harus menggunakan data awal (data sebelum transformasi). Peramalan suatu data baik dilakukan untuk jangka waktu yang pendek, sedangkan untuk jangka waktu yang relatif panjang hanya diperlukan untuk melihat kecenderungan (trend). Pada dasarnya, nilai peramalan jangka panjang ke depan kurang baik karena tidak akan diperoleh nilai emperis untuk residual setelah beberapa waktu, sehingga hal tersebut menyebabkan nilai harapan residual seluruhnya bernilai 0 dan angka prediksi kurang akurat.

\section{Hasil Penelitian dan Pembahasan}

Data yang digunakan dalam penelitian ini merupakan data sekunder, yaitu data input santri baru baik santri sputra maupun santri putri Pondok Pesantren Salafiyah Syafi'iyah Sukorejo Situbondo dari tahun 2005 hingga tahun 2016. Pengambilan data pada tahun tersebut, disesuaikan dengan database yang ada di kantor pusat pondok pesantren. Data sebelum periode tahun 2005 hingga awal mula adanya santri pada pendirian awal pondok tidak ada, sehingga tidak dapat dijadikan sebagai data untuk 
kegiatan dianalisis. Adapun hasil analisis data runtun waktu jumlah santri baru Pondok Pesantren Pesantren Salafiyah Syafi'iyah Sukorejo Situbondo dari tahun 2005 hingga tahun 2016 dengan model ARMA (p,q) sebagai berikut:

\section{Hasil Identifikasi Model ARMA}

Karena pada model ARMA sudah diasumsikan data stasioner, maka dilanjutkan pada langkah selanjutnya, yaitu membuat plot ACF dan PACF untuk mengidentifikasi model ARMA yang cocok untuk digunakan.

Gambar 1.1 Correlogram Data Santri(S)

\begin{tabular}{|c|c|c|c|c|c|c|c|c|}
\hline \multicolumn{9}{|c|}{ Correlogram of S } \\
\hline \multicolumn{9}{|c|}{$\begin{array}{l}\text { Date: } 12 / 01 / 16 \text { Time: } 18: 27 \\
\text { Sample: } 20052016 \\
\text { Included observations: } 12\end{array}$} \\
\hline Autocorr & elation & Partial Co & orrelation & & $\mathrm{AC}$ & PAC & Q-Stat & Prob \\
\hline 1 & & 1 & & 1 & 0.855 & 0.855 & 11.163 & 0.001 \\
\hline 1 & $\square$ & $1 \square$ & 1 & 2 & 0.604 & -0.472 & 17.291 & 0.000 \\
\hline 1 & $\square 1$ & $1 \square$ & 1 & 3 & 0.291 & -0.315 & 18.868 & 0.000 \\
\hline 1 & 1 & 1 & 1 & 4 & -0.015 & -0.122 & 18.873 & 0.001 \\
\hline $1 \square$ & 1 & 1 & 1 & 5 & -0.256 & -0.013 & 20.451 & 0.001 \\
\hline $1 \square$ & 1 & 1 & 1 & 6 & -0.416 & -0.076 & 25.301 & 0.000 \\
\hline$\square$ & 1 & 1 & 1 & 7 & -0.477 & -0.011 & 32.933 & 0.000 \\
\hline $1 \square$ & 1 & 1 & 1 & 8 & -0.447 & -0.001 & 41.308 & 0.000 \\
\hline $1 \square$ & 1 & 1 & 1 & 9 & -0.339 & 0.041 & 47.760 & 0.000 \\
\hline $1 \square$ & 1 & 1 & 1 & 10 & -0.207 & -0.091 & 51.349 & 0.000 \\
\hline I प & 1 & 다 & 1 & 11 & -0.092 & -0.138 & 52.776 & 0.000 \\
\hline
\end{tabular}

Data gambar correlogram ACF dan PACF di atas diketahui bahwa ACF tidak signifikan pada lag ke -1 dan ke-2 sehingga diduga data dibangkitkan oleh MA (2). Dari plot PACF diketahu bahwa tidak signifikan pada lag ke-1 sehingga diduga data dibangkitakan oleh AR(1), dengan demikian didapat model awal ARMA $(2,1)$. Walaupun tidak menutup kemungkinan terdapat model ARMA lain yang terbendtuk. Misalnya, model ARMA (1,1), ARMA $(1,2),(2,2)$, dll.

Model 1: ARMA $(2,1)$

Data $_{t}=\beta_{0}+\beta_{1}$ data $_{t-1}+\beta_{1}$ Data $_{t-2}+\alpha_{1} e_{t-1}+e_{t}$

Model 2: ARMA $(1,1)$

Data $_{t}=\beta_{0}+\beta_{1}$ data $_{t-1}+\alpha_{1} e_{t-1}+e_{t}$

66 JURNAL LISAN AL-HAL 
Model 3: ARMA $(1,0)$

Data $_{t}=\beta_{0}+\beta_{1}$ data $_{t-1}+e_{t}$

Model 4: ARMA $(0,1)$

Data $_{t}=\alpha_{0}+\alpha_{1} e_{t-1}+e_{t}$

Model 5: ARMA $(2,0)$

Data $_{t}=\beta_{0}+\beta_{1}$ data $_{t-1}+\beta_{1}$ Data $_{t-2}+e_{t}$

Setelah didapat model-model ARMA yang mungkin, langkah selanjutnya ialah melakukan estimasi terhadap parameter-parameternya. Langkah estimasi parameter dari model-model yang mungkin di atas ialah dengan melakukan uji hipotesis untuk setiap koefisien parameter yang dimiliki setiap yang dimiliki setiap model.

\section{Hasil Estimasi Model ARMA}

a. Model 1: ARMA (2,1)

Gambar 2.1 Hasil Analisis Model ARMA $(2,1)$

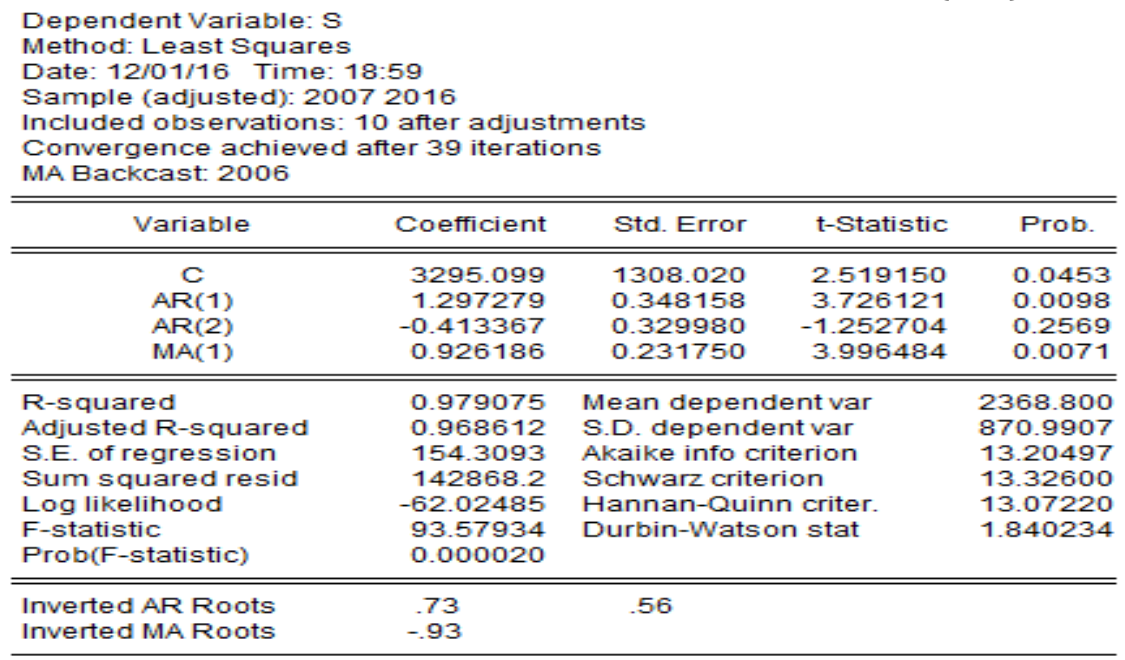

Hasil output di atas terlihat bahwa nilai koefisen $\mathrm{C}\left(\mathrm{C}=\beta_{0}\right)$ sebesar 3295,009, nilai statistik t-nya signifikan dengan nilai probabilitas di bawah atau sama dengan 0,05. Nilai koefisien AR (1) sebesar 1, 297279, nilai statistik t-nya signifikan dengan nilai probabilitas di bawah 0,05 . Selanjutnya, nilai koefisien AR (2) sebesar -0,413367, nilai statistik t-nya tidak signifikan dengan nilai probabilitas di atas 0,05. Sedangkan, nilai koefisien MA (1) sebesar 0,926186, nilai statistik t-nya signifikan dengan nilai probabilitas di bawah 0,05. Dengan demikian persamaan model 
ARMA $(2,1)$ adalah:

$$
\begin{gathered}
\text { Data }_{t}=3295,009+1,297279 \text { data }_{t-1}-0,413367 \text { Data }_{t-2} \\
+0,926186 e_{t-1}+e_{t}
\end{gathered}
$$

Berdasarkan analisa di atas diketahui bahwa parameter konstan, parameter AR (1) dan MA (1) adalah signifikan dalam model sedangkan parameter AR (2) tidak signifikan dalam model. Maka model tersebut tidak dapat dimasukkan ke dalam model ARMA $(2,1)$ sehingga ARMA $(2,1)$ tidak cocok untuk digunakan pada model yang mungkin.

b. Model 2: ARMA $(1,1)$

\begin{tabular}{|c|c|c|c|c|}
\hline C & 2711.297 & 618.6892 & 4.382325 & 0.0023 \\
\hline $\mathrm{AR}(1)$ & 0.874207 & 0.092863 & 9.413990 & 0.0000 \\
\hline $\mathrm{MA}(1)$ & 0.999631 & 0.272965 & 3.662116 & 0.0064 \\
\hline R-squared & 0.971649 & \multicolumn{2}{|c|}{ Mean dependent var } & 2254.000 \\
\hline Adjusted R-squared & 0.964562 & \multicolumn{2}{|c|}{ S.D. dependent var } & 909.7977 \\
\hline S.E. of regression & 171.2703 & \multicolumn{2}{|c|}{ Akaike info criterion } & 13.35136 \\
\hline Sum squared resid & 234668.2 & \multicolumn{2}{|c|}{ Schwarz criterion } & 13.45988 \\
\hline Log likelihood & -70.43250 & \multicolumn{2}{|c|}{ Hannan-Quinn criter. } & 13.28296 \\
\hline F-statistic & 137.0897 & \multicolumn{2}{|c|}{ Durbin-Watson stat } & 0.984633 \\
\hline Prob(F-statistic) & 0.000001 & & & \\
\hline Inverted AR Roots & .87 & & & \\
\hline Inverted MA Roots & -1.00 & & & \\
\hline
\end{tabular}

Gambar 2.2 Hasil Analisis Model ARMA (1,1)

Hasil output di atas terlihat bahwa nilai koefisen $C\left(\mathrm{C}=\beta_{0}\right)$ sebesar 2711,297, nilai statistik t-nya signifikan dengan nilai probabilitas di bawah 0,05. Nilai koefisien AR (1) sebesar 0,874207, nilai statistik t-nya signifikan dengan nilai probabilitas di bawah 0,05. Sedangkan, nilai koefisien MA (1) sebesar 0,999631, nilai statistik t-nya signifikan dengan nilai probabilitas di bawah 0,05 . Dengan demikian, persamaan model ARMA $(1,1)$ adalah:

Data $_{t}=2711,297+0,874207$ data $_{t-1}+0,999631 e_{t-1}+e_{t}$ 
Berdasarkan analisa di atas diketahui bahwa parameter konstan, parameter AR (1) dan MA (1) adalah signifikan dalam model. Maka model tersebut dapat dimasukkan ke dalam model ARMA $(1,1)$ sehingga ARMA $(1,1)$ cocok untuk digunakan pada model yang mungkin.

c. Model 3: ARMA $(1,0)$

\section{Gambar 2.3 Hasil Analisis Model ARMA (1,0)}

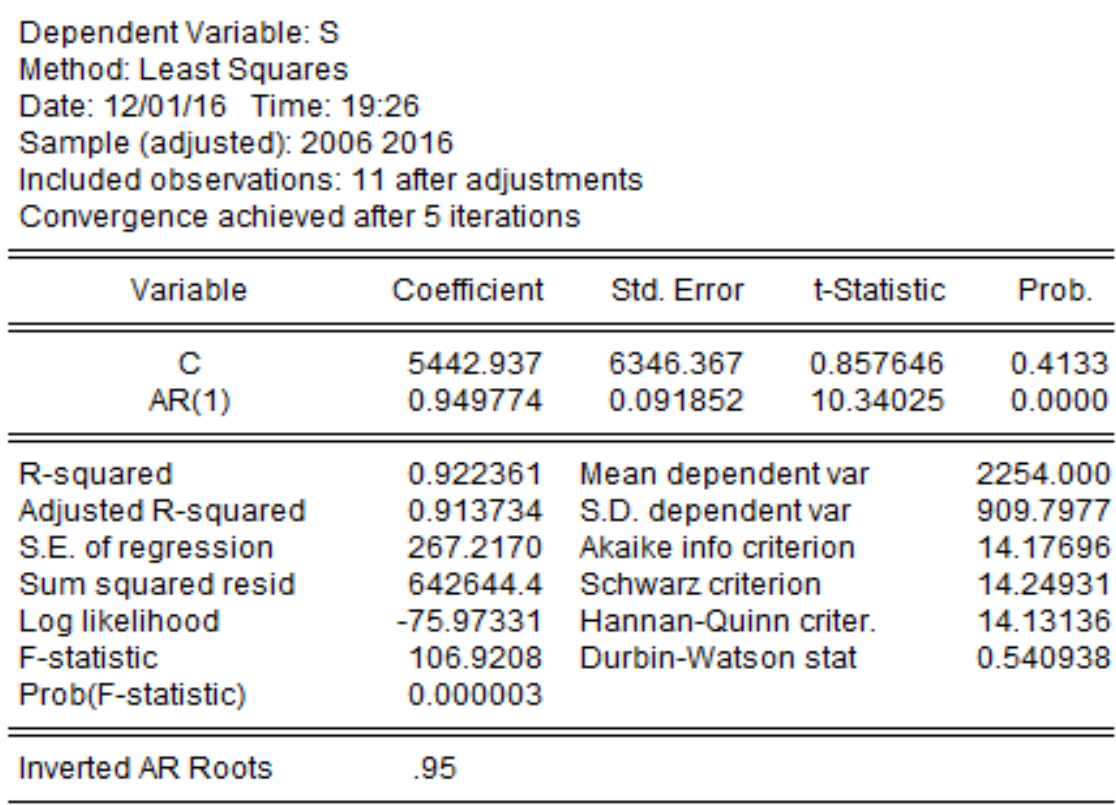

Hasil output di atas terlihat bahwa nilai koefisen $C\left(C=\beta_{0}\right)$ sebesar 5442,937, nilai statistik t-nya tidak signifikan dengan nilai probabilitas di atas 0,05. Sedangkan, nilai koefisien AR (1) sebesar 0,949774, nilai statistik t-nya signifikan dengan nilai probabilitas di bawah 0,05. Dengan demikian, persamaan model ARMA $(1,0)$ adalah:

Data $_{t}=5442,937+0,949774$ data $_{t-1}+e_{t}$

Berdasarkan analisa di atas diketahui bahwa parameter konstan, parameter AR (1) adalah signifikan dalam model. Maka model tersebut dapat dimasukkan ke dalam model ARMA $(1,0)$ sehingga ARMA $(1,0)$ cocok untuk digunakan pada model yang mungkin.

d. Model 4: ARMA $(0,1)$

Gambar 2.4 Hasil Analisis Model ARMA $(0,1)$ 


\begin{tabular}{|c|c|c|c|c|}
\hline $\mathrm{MA}(1)$ & 0.931818 & 0.070240 & 13.26622 & 0.0000 \\
\hline R-squared & 0.721565 & \multicolumn{2}{|c|}{ Mean dependent var } & 2165.500 \\
\hline Adjusted R-squared & 0.693721 & \multicolumn{2}{|c|}{ S.D. dependent var } & 920.0383 \\
\hline S.E. of regression & 509.1718 & \multicolumn{2}{|c|}{ Akaike info criterion } & 15.45446 \\
\hline Sum squared resid & 2592559. & \multicolumn{2}{|c|}{ Schwarz criterion } & 15.53528 \\
\hline Log likelihood & -90.72676 & \multirow{2}{*}{\multicolumn{2}{|c|}{$\begin{array}{l}\text { Hannan-Quinn criter. } \\
\text { Durbin-Watson stat }\end{array}$}} & 15.42454 \\
\hline F-statistic & 25.91500 & & & 0.277410 \\
\hline Prob(F-statistic) & 0.000470 & & & \\
\hline Inverted MA Roots & -.93 & & & \\
\hline
\end{tabular}

Hasil output di atas terlihat bahwa nilai koefisen $C\left(C=\beta_{0}\right)$ sebesar 2267,704 nilai statistik t-nya signifikan dengan nilai probabilitas di bawah 0,05. Sedangkan, nilai koefisien MA (1) sebesar 0,931818, nilai statistik tnya signifikan dengan nilai probabilitas di bawah 0,05 . Dengan demikian, Persamaan model ARMA $(0,1)$ data dari hasil estimasi di atas adalah: Data $_{t}=2267,704+0,931818 e_{t-1}+e_{t}$

Berdasarkan analisa di atas diketahui bahwa parameter konstan, parameter MA (1) adalah signifikan dalam model. Maka model tersebut dapat dimasukkan ke dalam model ARMA $(0,1)$ sehingga ARMA $(0,1)$ cocok untuk digunakan pada model yang mungkin.

e. Model 5: ARMA $(2,0)$

Gambar 2.5 Hasil Analisis Model ARMA $(2,0)$

$70 \quad$ JURNAL LISAN AL-HAL 


\begin{tabular}{|c|c|c|c|c|}
\hline \multicolumn{5}{|c|}{$\begin{array}{l}\text { Dependent Variable: S } \\
\text { Method: Least Squares } \\
\text { Date: 12/01/16 Time: } 19: 35 \\
\text { Sample (adjusted): } 20072016 \\
\text { Included observations: } 10 \text { after adjustments } \\
\text { Convergence achieved after } 3 \text { iterations }\end{array}$} \\
\hline Variable & Coefficient & Std. Error & t-Statistic & Prob. \\
\hline $\begin{array}{c}\mathrm{C} \\
\mathrm{AR}(1) \\
\mathrm{AR}(2)\end{array}$ & $\begin{array}{r}2368.067 \\
1.689962 \\
-0.834506\end{array}$ & $\begin{array}{l}462.4108 \\
0.204659 \\
0.210975\end{array}$ & $\begin{array}{r}5.121133 \\
8.257469 \\
-3.955480\end{array}$ & $\begin{array}{l}0.0014 \\
0.0001 \\
0.0055\end{array}$ \\
\hline $\begin{array}{l}\text { R-squared } \\
\text { Adjusted R-squared } \\
\text { S.E. of regression } \\
\text { Sum squared resid } \\
\text { Log likelihood } \\
\text { F-statistic } \\
\text { Prob(F-statistic) }\end{array}$ & $\begin{array}{r}0.975890 \\
0.969001 \\
153.3509 \\
164615.4 \\
-62.73330 \\
141.6668 \\
0.000002\end{array}$ & \multicolumn{2}{|c|}{$\begin{array}{l}\text { Mean dependent var } \\
\text { S.D. dependent var } \\
\text { Akaike info criterion } \\
\text { Schwarz criterion } \\
\text { Hannan-Quinn criter. } \\
\text { Durbin-Watson stat }\end{array}$} & $\begin{array}{l}2368.800 \\
870.9907 \\
13.14666 \\
13.23743 \\
13.04708 \\
1.685665\end{array}$ \\
\hline Inverted AR Roots & $.84+.35 i$ & $.84-.35 i$ & & \\
\hline
\end{tabular}

Hasil output di atas terlihat bahwa nilai koefisen $C\left(C=\beta_{0}\right)$ sebesar 2368,067, nilai statistik t-nya signifikan dengan nilai probabilitas di bawah 0,05.Nilai koefisien AR (1) sebesar 1,689962, nilai statistik t-nya signifikan dengan nilai probabilitas di bawah 0,05. Sedangkan, nilai koefisien AR (2) sebesar -0,834506, nilai statistik t-nya signifikan dengan nilai probabilitas di bawah 0,05. Dengan demikian, persamaan model ARMA $(0,1)$ data dari hasil estimasi di atas adalah:

$$
\text { Data }_{t}=2368,067+1,689962 \text { data }_{t-1}-0,834506 \text { data }_{t-1}+e_{t}
$$

Berdasarkan analisa di atas diketahui bahwa parameter konstan, parameter AR (1) dan AR (2) adalah signifikan dalam model. Maka model tersebut dapat dimasukkan ke dalam model ARMA $(2,0)$ sehingga ARMA $(2,0)$ cocok untuk digunakan pada model yang mungkin.

\section{Uji Diagnosis Model}

Setelah di dapat model-model yang mungkin, langkah selanjutnya ialah melakukan uji diagnosis atau uji asumsi residual untuk model yang terpilih meliputi: Uji Normalitas, Uji Non-Autokorelasi, dan Uji homoskedastisitas. Uji normalitas model digunakan untuk mengatahui kenormalan dari residual. Kemudian, uji non-autokorelasi digunakan untuk mengetahui apakah residual mengandung autokorelasi atau tidak. 
Sedangkan, uji homoskedastisitas digunakan untuk mengetahui apakah varians residual homogen atau tidak.

Adapun dasar pengambilan keputusan pada uji normalitas ialah jika nilai signifikansi Jargue Berra (JB) $>0,05$ maka residual data berdistribusi normal. Pada uji non-autokorelasi, jika nilai probabilitas Q-statistik $>0,05$ maka residual data tidak mengandung autokorelasi. Sedangkan, pengambilan keputusan untuk uji homoskedastisitas ialah jika nilai probabilitas Chi-Square (pada obs* R-squared) > 0,05 maka varians residual data bersifat homogen (homoskedastisitas).

a. Model ARMA $(1,1)$

Uji Normalitas

Gambar 3.1 Hasil Analisis Pengujian Model ARMA $(2,0)$

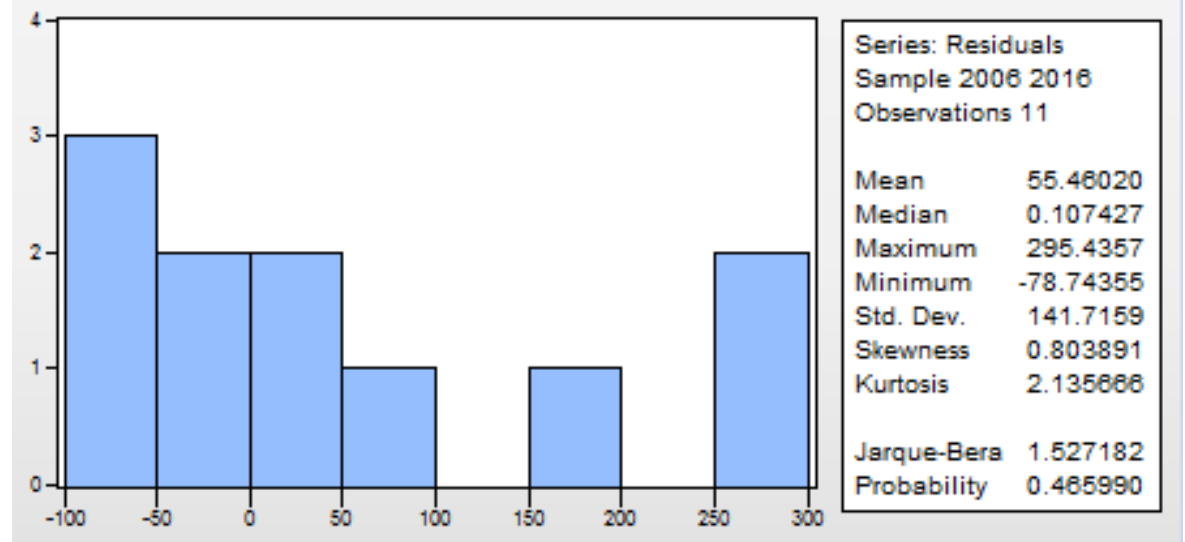

Berdasarkan output di atas, diketahui bahwa probabilitas $J B=0,465990>0,05$, maka residual data berdistribusi normal.

Uji Non-Autokorelasi

Gambar 3.2 Hasil Analisis Pengujian Model ARMA $(2,0)$

72 JURNAL LISAN AL-HAL 
Date: 12/01/16 Time: 19:46

Sample: 20052016

Included observations: 11

Q-statistic probabilities adjusted for 2 ARMA terms

\begin{tabular}{clllll|rrrrr}
\hline \hline \multicolumn{2}{c}{ Autocorrelation } & \multicolumn{2}{c}{ Partial Correlation } & & AC & PAC & Q-Stat & Prob \\
\hline \hline
\end{tabular}

Pada output di atas terlihat bahwa nilai probabilitas data lebih besar dari tingkat signifikan $\alpha=0,05$ meskipun tidak secara keseluruhan. Dengan demikian residual data tidak mengandung autokorelasi. Hal ini juga diperkuat dengan plot ACF dan PACF, dimana lag-lag awal secara signifikan berada di dalam batas interval konfidensi. Sehingga dapat disimpulkan bahwa plot data di atas menunjukkan tidak terdapat autokorelasi pada residual.

\section{Uji Homoskedastisitas}

Gambar 3.3 Hasil Analisis Pengujian Model ARMA $(2,0)$

\begin{tabular}{|c|c|c|c|c|}
\hline $\begin{array}{l}\text { F-statistic } \\
\text { Obs*R-squared } \\
\text { Scaled explained Ss }\end{array}$ & $\begin{array}{l}4.044779 \\
10.35969 \\
6.279620\end{array}$ & \multicolumn{2}{|c|}{$\begin{array}{l}\text { Prob. } F(8,2) \\
\text { Prob. Chi-Square(8) } \\
\text { Prob. Chi-Square( } 8 \text { ) }\end{array}$} & $\begin{array}{l}0.2133 \\
0.2407 \\
0.6159\end{array}$ \\
\hline \multicolumn{5}{|c|}{$\begin{array}{l}\text { Test Equation: } \\
\text { Dependent Variable: RESID^2 } \\
\text { Method: Least Squares } \\
\text { Date: } 12 / 01 / 16 \text { Time: } 20: 53 \\
\text { Sample: } 20062016 \\
\text { Included observations: } 11 \\
\text { Collinear test regressors dropped from specification }\end{array}$} \\
\hline Variable & Coefficient & Std. Error & t-Statistic & Prob. \\
\hline $\begin{array}{c}\text { C } \\
\text { GRADF_01^2 } \\
\text { GRADF_01*GRADF_02 } \\
\text { GRADF_01*GRADF_03 } \\
\text { GRADF_01 } \\
\text { GRADF_02^2 } \\
\text { GRADF_02*GRADF_03 } \\
\text { GRADF-02 } \\
\text { GRADF_03n2 }\end{array}$ & $\begin{array}{r}-8511445 \\
5.89 E+09 \\
516214.2 \\
443.2460 \\
-6.20 E+08 \\
-0.251437 \\
0.119250 \\
-32471.54 \\
0.000121\end{array}$ & $\begin{array}{l}20362601 \\
4.13 E+09 \\
253890.7 \\
827.7351 \\
3.77 E+08 \\
0.078585 \\
0.058778 \\
16007.46 \\
0.000280\end{array}$ & $\begin{array}{r}-0.417994 \\
1.426012 \\
2.033215 \\
0.535492 \\
-1.643078 \\
-3.199569 \\
2.028820 \\
-2.028525 \\
0.430532\end{array}$ & $\begin{array}{l}0.7166 \\
0.2900 \\
0.1791 \\
0.6459 \\
0.2421 \\
0.0854 \\
0.1796 \\
0.1797 \\
0.7088\end{array}$ \\
\hline $\begin{array}{l}\text { Adjusted R-squared } \\
\text { S.E. of regression } \\
\text { Sum squared resid }\end{array}$ & $\begin{array}{l}0.941790 \\
0.708949 \\
18274.84 \\
6.68 E+08\end{array}$ & $\begin{array}{l}\text { S.D. depend } \\
\text { Akaike info CI } \\
\text { Schwarz crite }\end{array}$ & $\begin{array}{l}\text { itvar } \\
\text { erion } \\
\text { on }\end{array}$ & $\begin{array}{l}21333.47 \\
33874.19 \\
22.39605 \\
22.72160\end{array}$ \\
\hline
\end{tabular}

Berdasarkan uji white di atas, diketahui bahwa nilai obs* $R$ squared adalah sebesar 10,35969 sedangkan nilai probabilitas (chisquare) adalah 0,2407 (lebih besar dari nilai $\alpha=0,05$ ), dengan demikian residual data homoskedastisitas. 
b. Model $(1,0)$

Uji Normalitas

Gambar 3.4 Hasil Analisis Pengujian Model ARMA (1,0)

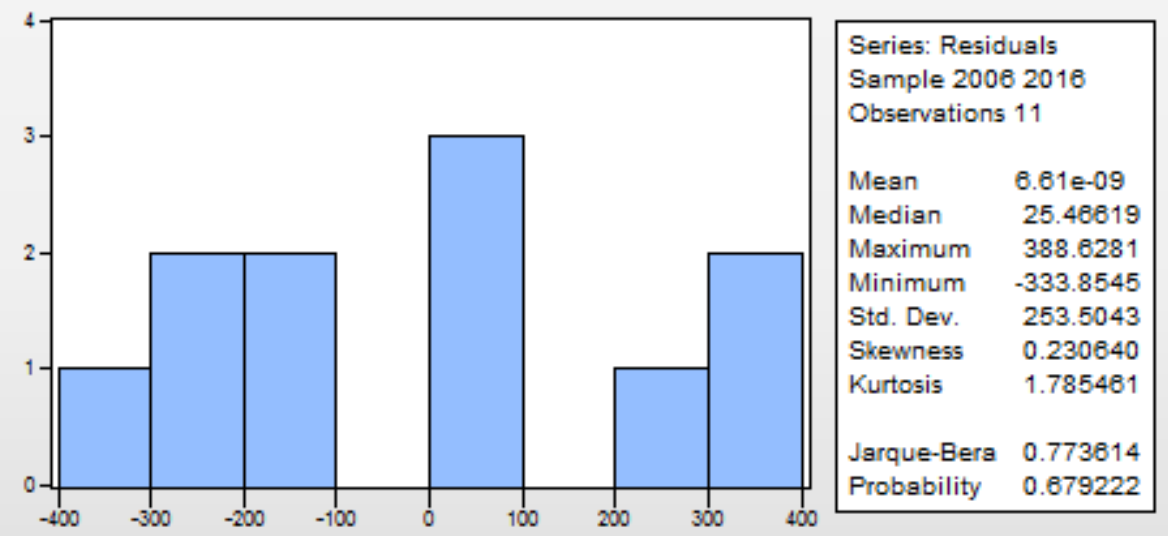

Berdasarkan output di atas, diketahui bahwa probabilitas $J B=0,679222>0,05$, maka residual data berdistribusi normal.

Uji Non-Autokorelasi

Gambar 3.5 Hasil Analisis Pengujian Model ARMA (1,0)

Date: 12/01/16 Time: 20:22

Sample: 20052016

Included observations: 11

Q-statistic probabilities adjusted for 1 ARMA term

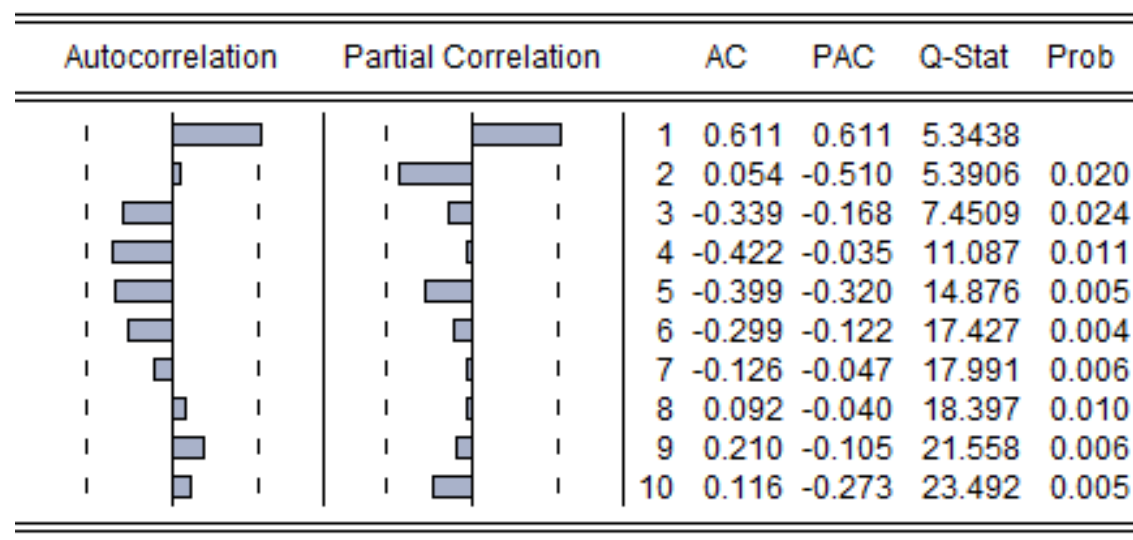

Pada output di atas terlihat bahwa nilai probabilitas data kurang dari tingkat signifikan $\alpha=0,05$. Dengan demikian, residual data mengandung autokorelasi. Hal ini juga diperkuat dengan plot ACF dan PACF, dimana lag-lag awal secara tidak signifikan berada di diluar batas interval

74 JURNAL LISAN AL-HAL 
konfidensi. Sehingga dapat disimpulkan bahwa plot data di atas menunjukkan terdapat autokorelasi pada residual.

Uji Homoskedastisitas

Gambar 3.6 Hasil Analisis Pengujian Model ARMA (2,0)

Heteroskedasticity Test: White

\begin{tabular}{llll}
\hline \hline F-statistic & 1.919069 & Prob. F(2,8) & 0.2086 \\
Obs*R-squared & 3.566399 & Prob. Chi-Square(2) & 0.1681 \\
Scaled explained SS & 0.937614 & Prob. Chi-Square(2) & 0.6257 \\
\hline \hline
\end{tabular}

Test Equation:

Dependent Variable: RESID 2

Method: Least Squares

Date: 12/01/16 Time: 21:00

Sample: 20062016

Included observations: 11

Collinear test regressors dropped from specification

\begin{tabular}{lrlll}
\hline \hline \multicolumn{1}{c}{ Variable } & Coefficient & Std. Error & t-Statistic & Prob. \\
\hline \hline \multicolumn{1}{c}{ C } & -339242.0 & 328147.7 & -1.033809 & 0.3315 \\
GRADF_01*GRADF_02 & -5910.734 & 4352.727 & -1.357938 & 0.2115 \\
$\quad$ GRADF_02^2 & -0.049748 & 0.033968 & -1.464568 & 0.1812 \\
\hline \hline R-squared & 0.324218 & Mean dependent var & 58422.22 \\
Adjusted R-squared & 0.155273 & S.D. dependent var & 54304.60 \\
S.E. of regression & 49910.84 & Akaike info criterion & 24.70087 \\
Sum squared resid & $1.99 E+10$ & Schwarz criterion & 24.80938 \\
Log likelihood & -132.8548 & Hannan-Quinn criter. & 24.63246 \\
F-statistic & 1.919069 & Durbin-Watson stat & 1.976351 \\
Prob(F-statistic) & 0.208558 & & \\
\hline \hline
\end{tabular}

Berdasarkan uji white di atas, diketahui bahwa nilai obs* $R$-squared adalah sebesar 3,566399 sedangkan nilai probabilitas (chi-square) adalah 0,1681 (lebih besar dari nilai $\alpha=0,05$ ), dengan demikian residual data homoskedastisitas.

c. Model $(0,1)$

Uji Normalitas

Gambar 3.7 Hasil Analisis Pengujian Model ARMA (0,1) 


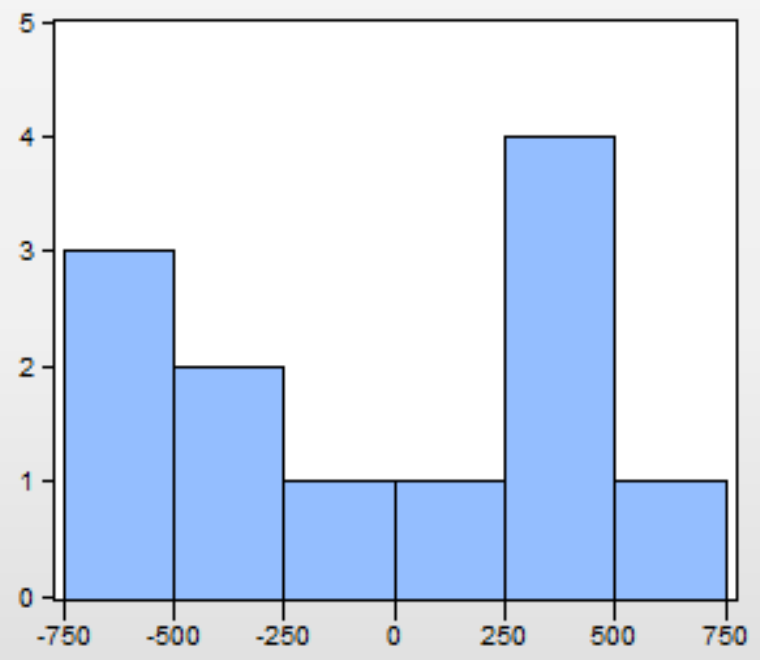

\begin{tabular}{|c|c|}
\hline \multicolumn{2}{|c|}{$\begin{array}{l}\text { Series: Residuals } \\
\text { Sample } 20052016 \\
\text { Observations } 12\end{array}$} \\
\hline Mean & -14.68054 \\
\hline Median & 3.450141 \\
\hline Maximum & 711.1293 \\
\hline Minimum & -683.5637 \\
\hline Std. Dev. & 485.2340 \\
\hline Skewness & 0.011971 \\
\hline Kurtosis & 1.457634 \\
\hline Jarque-Bera & 1.189733 \\
\hline Probability & 0.551636 \\
\hline
\end{tabular}

Berdasarkan output di atas, diketahui bahwa probabilitas $J B=0,551636>0,05$, maka residual data berdistribusi normal.

Uji Non-Autokorelasi

Gambar 3.8 Hasil Analisis Pengujian Model ARMA $(0,1)$

Date: $12 / 01 / 16$ Time: $20: 26$

Sample: 20052016

Included observations: 12

Q-statistic probabilities adjusted for 1 ARMA term

\begin{tabular}{|c|c|c|c|c|c|c|c|c|}
\hline \multicolumn{2}{|c|}{ Autocorrelation } & \multicolumn{2}{|c|}{ Partial Correlation } & & $A C$ & PAC & Q-Stat & Prob \\
\hline 1 & & 1 & & 1 & 0.788 & 0.788 & 9.4813 & \\
\hline 1 & $\square$ & 1 & 1 & 2 & 0.596 & -0.066 & 15.445 & 0.000 \\
\hline 1 & $\boxminus \quad 1$ & $\square$ & 1 & 3 & 0.258 & -0.505 & 16.685 & 0.000 \\
\hline 1 & 1 & 당 & 1 & 4 & -0.018 & -0.148 & 16.692 & 0.001 \\
\hline $1 \square$ & 1 & I & 1 & 5 & -0.272 & -0.065 & 18.465 & 0.001 \\
\hline $1 \square$ & 1 & 다 & 1 & 6 & -0.430 & -0.085 & 23.650 & 0.000 \\
\hline $1 \square$ & 1 & I & 1 & 7 & -0.461 & 0.109 & 30.789 & 0.000 \\
\hline $1 \square$ & 1 & 1 & 1 & 8 & -0.425 & -0.033 & 38.366 & 0.000 \\
\hline $1 \square$ & 1 & I & 1 & 9 & -0.280 & 0.052 & 42.761 & 0.000 \\
\hline $1 \square$ & 1 & $1 \square$ & 1 & 10 & -0.186 & -0.202 & 45.653 & 0.000 \\
\hline 1 & 1 & 디 & 1 & 11 & -0.070 & -0.124 & 46.468 & 0.000 \\
\hline
\end{tabular}

Pada output di atas terlihat bahwa nilai probabilitas data kurang dari tingkat signifikan $\alpha=0,05$. Dengan demikian, residual data mengandung autokorelasi. Hal ini juga diperkuat dengan plot ACF dan PACF, dimana lag-lag awal secara tidak signifikan berada di diluar batas interval 76 JURNAL LISAN AL-HAL 
konfidensi. Sehingga dapat disimpulkan bahwa plot data di atas menunjukkan terdapat autokorelasi pada residual.

\section{Uji Homoskedastisitas}

Gambar 3.9 Hasil Analisis Pengujian Model ARMA $(0,1)$

Heteroskedasticity Test: White

\begin{tabular}{llll}
\hline \hline F-statistic & 2.455779 & Prob. F(5,6) & 0.1523 \\
Obs*R-squared & 8.061031 & Prob. Chi-Square(5) & 0.1529 \\
Scaled explained SS & 1.285279 & Prob. Chi-Square(5) & 0.9364 \\
\hline \hline
\end{tabular}

Test Equation:

Dependent Variable: RESID 2

Method: Least Squares

Date: 12/01/16 Time: 21:02

Sample: 20052016

Included observations: 12

\begin{tabular}{lrrrr}
\hline \hline \multicolumn{1}{c}{ Variable } & Coefficient & Std. Error & t-Statistic & Prob. \\
\hline \hline C & 22521075 & 10925697 & 2.061294 & 0.0849 \\
GRADF_01^2 & 90982982 & 40949431 & 2.221838 & 0.0680 \\
GRADF_01*GRADF_02 & 10627.80 & 6063.450 & 1.752764 & 0.1302 \\
GRADF_01 & -89429063 & 42224397 & -2.117948 & 0.0785 \\
GRADF_02^2 & 0.192381 & 0.239097 & 0.804616 & 0.4517 \\
GRADF_02 & -5197.063 & 3182.379 & -1.633075 & 0.1536 \\
\hline \hline R-squared & 0.671753 & Mean dependent var & 216046.6 \\
Adjusted R-squared & 0.398213 & S.D. dependent var & 152911.9 \\
S.E. of regression & 118621.3 & Akaike info criterion & 26.51211 \\
Sum squared resid & $8.44 E+10$ & Schwarz criterion & 26.75457 \\
Log likelihood & -153.0727 & Hannan-Quinn criter. & 26.42235 \\
F-statistic & 2.455779 & Durbin-Watson stat & 0.998642 \\
Prob(F-statistic) & 0.152305 & & & \\
\hline \hline
\end{tabular}

Berdasarkan uji white di atas, diketahui bahwa nilai obs* $R$-squared adalah sebesar 8,061031 sedangkan nilai probabilitas (chi-square) adalah 0,1529 (lebih besar dari nilai $\alpha=0,05$ ), dengan demikian residual data homoskedastisitas.

d. Model $(2,0)$

Uji Normalitas

\section{Gambar 3.10 Hasil Analisis Pengujian Model ARMA $(2,0)$}




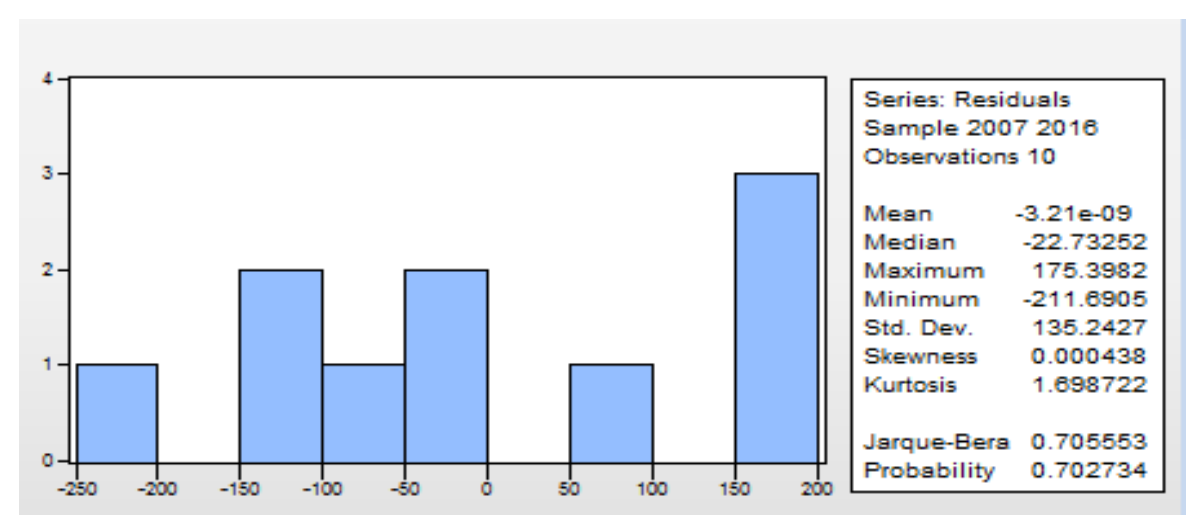

Berdasarkan output di atas, diketahui bahwa probabilitas $J B=0,702734>0,05$, maka residual data berdistribusi normal.

\section{Uji Non-Autokorelasi}

\section{Gambar 3.11 Hasil Analisis Pengujian Model ARMA $(2,0)$}

Date: 12/01/16 Time: 20:32

Sample: 20052016

Included observations: 10

Q-statistic probabilities adjusted for 2 ARMA terms

\begin{tabular}{|c|c|c|c|c|c|c|c|c|}
\hline \multicolumn{2}{|c|}{ Autocorrelation } & \multicolumn{2}{|c|}{ Partial Correlation } & & $\mathrm{AC}$ & PAC & Q-Stat & Prob \\
\hline 1 & 1 & 1 & 1 & 1 & 0.060 & 0.060 & 0.0485 & \\
\hline$\square$ & 1 & $1 \square$ & 1 & 2 & -0.268 & -0.273 & 1.1286 & \\
\hline $1 \square$ & 1 & $1 \square$ & 1 & 3 & -0.372 & -0.363 & 3.5024 & 0.061 \\
\hline 1 단 & 1 & $1 \square$ & 1 & 4 & -0.153 & -0.257 & 3.9713 & 0.137 \\
\hline 1 & 1 & 1 & 1 & 5 & 0.171 & -0.060 & 4.6711 & 0.198 \\
\hline 1 & 1 & 1 & 1 & 6 & 0.016 & -0.299 & 4.6792 & 0.322 \\
\hline 1 & 1 & I & 1 & 7 & 0.175 & 0.039 & 5.8986 & 0.316 \\
\hline 1 & 1 & $\square$ & 1 & 8 & -0.093 & -0.211 & 6.4133 & 0.379 \\
\hline 1 & 1 & प & 1 & 9 & -0.036 & -0.064 & 6.5677 & 0.475 \\
\hline
\end{tabular}

Pada output di atas terlihat bahwa nilai probabilitas data lebih dari tingkat signifikan $\alpha=0,05$ meskipun tidak secara keseluruhan. Dengan demikian, residual data tidak mengandung autokorelasi. Hal ini juga diperkuat dengan plot ACF dan PACF, dimana lag-lag awal secara signifikan berada di dalam batas interval konfidensi. Sehingga dapat disimpulkan bahwa plot data di atas menunjukkan tidak terdapat autokorelasi pada residual.

\section{Uji Homoskedastisitas}

$$
78 \mid \text { JURNAL LISAN AL-HAL }
$$


Gambar 3.12 Hasil Analisis Pengujian Model ARMA $(2,0)$ Heteroskedasticity Test: White

\begin{tabular}{llll}
\hline \hline F-statistic & 2.787701 & Prob. F(5,4) & 0.1711 \\
Obs*R-squared & 7.770160 & Prob. Chi-Square(5) & 0.1694 \\
Scaled explained SS & 1.330149 & Prob. Chi-Square(5) & 0.9318 \\
\hline \hline
\end{tabular}

\begin{tabular}{|c|c|c|c|c|}
\hline & 51467.27 & 31249.66 & 1.646971 & 0.1749 \\
\hline GRADF_01*GRADF_03 & -67.15412 & 224.9980 & -0.298465 & 0.7802 \\
\hline GRADF $02^{\wedge} 2$ & -0.185904 & 0.089699 & -2.072540 & 0.1069 \\
\hline GRADF_02*GRADF_03 & 0.348199 & 0.177754 & 1.958885 & 0.1217 \\
\hline GRADF_0 $03^{\wedge} 2$ & -0.183747 & 0.108270 & -1.697122 & 0.1649 \\
\hline R-squared & 0.777016 & \multicolumn{2}{|c|}{ Mean dependent var } & 16461.54 \\
\hline Adjusted R-squared & 0.498286 & \multicolumn{2}{|c|}{ S.D. dependent var } & 14504.45 \\
\hline S.E. of regression & 10273.76 & \multicolumn{2}{|c|}{ Akaike info criterion } & 21.59628 \\
\hline Sum squared resid & $4.22 E+08$ & \multicolumn{2}{|c|}{ Schwarz criterion } & 21.77783 \\
\hline Log likelihood & -101.9814 & \multirow{2}{*}{\multicolumn{2}{|c|}{ Hannan-Quinn criter. }} & 21.39712 \\
\hline F-statistic & 2.787701 & & & 2.217954 \\
\hline Prob(F-statistic) & 0.171120 & \multicolumn{2}{|c|}{ Durbin-Watson stat } & \\
\hline
\end{tabular}

Berdasarkan uji white di atas, diketahui bahwa nilai obs* $R$-squared adalah sebesar 7,770160 sedangkan nilai probabilitas (chi-square) adalah 0,1694 (lebih besar dari nilai $\alpha=0,05$ ), dengan demikian residual data homoskedastisitas.

Selanjutnya, setelah melakukan estimasi parameter untuk masingmasing model, maka selanjutnya kita melakukan pemilihan model terbaik dari semua kemungkinan model yang telah memenuhi uji diagnosis atau uji asumsi normalitas, non-autokorelasi, dan homoskedastisitas dengan cara melihat ukuran-ukuran standar ketepatan peramalan. Tabel perbandingan ARMA sebagai berikut:

Tabel 3.1 Perbandingan Model Berdasarkan Nilai SSR, AIC , dan SIC

\begin{tabular}{|l|l|l|l|l|} 
Nama & ARMA & ARMA & ARMA & ARMA $(2,0)$ \\
\hline
\end{tabular}




\begin{tabular}{|c|c|c|c|c|}
\hline & $(1,1)$ & $(1,0)$ & $(0,1)$ & \\
\hline SSR & 234668,2 & 642644,4 & 2592559,0 & 164615,4 \\
\hline AIC & 13,353136 & 14,17696 & 15,45446 & 13,14666 \\
\hline SIC & 13,45988 & 14,24931 & 15,53528 & 13,23743 \\
\hline
\end{tabular}

Tabel 3.2 Perbandingan Model Berdasarkan Uji Asumsi

\begin{tabular}{|c|c|c|c|}
\hline MODEL & Normalitas & $\begin{array}{c}\text { Non } \\
\text { Autokorelasi }\end{array}$ & $\begin{array}{c}\text { Homoskedastisita } \\
\text { s }\end{array}$ \\
\hline ARMA $(1,1)$ & $\sqrt{ }$ & $\sqrt{ }$ & $\sqrt{ }$ \\
\hline ARMA $(1,0)$ & $\sqrt{ }$ & - & $\sqrt{ }$ \\
\hline ARMA $(0,1)$ & $\sqrt{ }$ & - & $\sqrt{ }$ \\
\hline ARMA $(2,0)$ & $\sqrt{ }$ & $\sqrt{ }$ & $\sqrt{ }$ \\
\hline
\end{tabular}

Berdasarkan tabel di atas, dapat dianalisis sebagai berikut:Pertama, untuk model ARMA $(1,1)$ diketahui bahwa uji statistik t-nya signifikan dan uji residul menunjukkan bahwa residual berdistribusi normal, bersifat non-autokorelasi, dan homoskedastisitas. Dengan demikian, model ARMA $(1,1)$ dapat dipertimbangkan sebagai model yang cocok untuk data di atas.Kedua, untuk model ARMA $(1,0)$ diketahui bahwa uji statistik t-nya signifikan dan uji residul menunjukkan bahwa residual berdistribusi normal, dan homoskedastisitas. Akan tetapi tidak terbebas dari korelasi serial dalam data (bersifat autokorelasi). Dengan demikian, model ARMA $(1,0)$ tidak dapat dipertimbangkan sebagai model yang cocok untuk data di atas.Ketiga, untuk model ARMA $(0,1)$ diketahui bahwa uji statistik t-nya signifikan dan uji residul menunjukkan bahwa residual berdistribusi normal, dan homoskedastisitas. Akan tetapi tidak terbebas dari korelasi serial dalam data (bersifat autokorelasi). Dengan demikian, model ARMA $(0,1)$ tidak dapat dipertimbangkan sebagai model yang cocok untuk data di atas.Terakhir, untuk model ARMA $(2,0)$ diketahui bahwa uji statistik tnya signifikan dan uji residul menunjukkan bahwa residual berdistribusi normal, bersifat non-autokorelasi, dan homoskedastisitas. Dengan demikian, model ARMA $(2,0)$ dapat dipertimbangkan sebagai model untuk data di atas.

Selanjutnya, model yang dapat dibandingkan sebagai model terbaik ialah hanya model ARMA $(1,1)$ dan model ARMA $(2,0)$. Untuk memilih model terbaik dari kedua model tersebut digunakan kriteri AIC serta mempertimbangkan kriteria lain seperti BIC dan SSR.

Berdasarkan nilai SSR, AIC, dan BIC pada gambar tampak bahwa model ARMA $(2,0)$ mempunyai nilai SSR, AIC, dan BIC minimum

80 $\mid$ JURNAL LISAN AL-HAL 
dibandingkan dengan model ARMA (1,1). Oleh karena itu, dapat disimpulkan bahwa model ARMA $(2,0)$ adalah model yang terbaik untuk data input santri baru Pondok Pesantren Salafiyah Syafi'iyah Sukorejo Situbondo dri tahun 2005 hingga tahun 2016.

Adapun persamaan model ARMA $(2,0)$ untuk data input santri baru Pondok Pesantren Salafiyah Syafi'iyah Sukorejo Situbondo dari tahun 2005 hingga tahun 2016, secara umum ditulis:

Data $_{t}=2.368,067+1,689962$ data $_{t-1}-0,834506$ data $_{t-2}+e_{t}$ Keterangan:

$$
\begin{aligned}
\text { Data }_{t} & =\text { observasi periode ke-t } \\
\text { Data }_{t-1} & =\text { observasi data satu tingkat sebelum periode ke }-\mathrm{t} \\
e_{t} & =\text { nilai residual data ke }-\mathrm{t}
\end{aligned}
$$

\section{Peramalan (Forcasting)}

Langkah terakhir dalam analisi time series data ialah melakukan peramalan (forcasting) data untuk periode selanjutnya dengan menggunakan model ARMA (p,q) terbaik, yaitu model ARMA (2,0).Dalam pembahasan ini akan diramalkan jumlah santri baru Pondok Pesantren Salafiyah Syafi'iyah Sukorejo Situbondo pada tahun 2007-2016.

Gambar 3.14Grafik Perbandingan Data Aktual dengan Data Ramalan

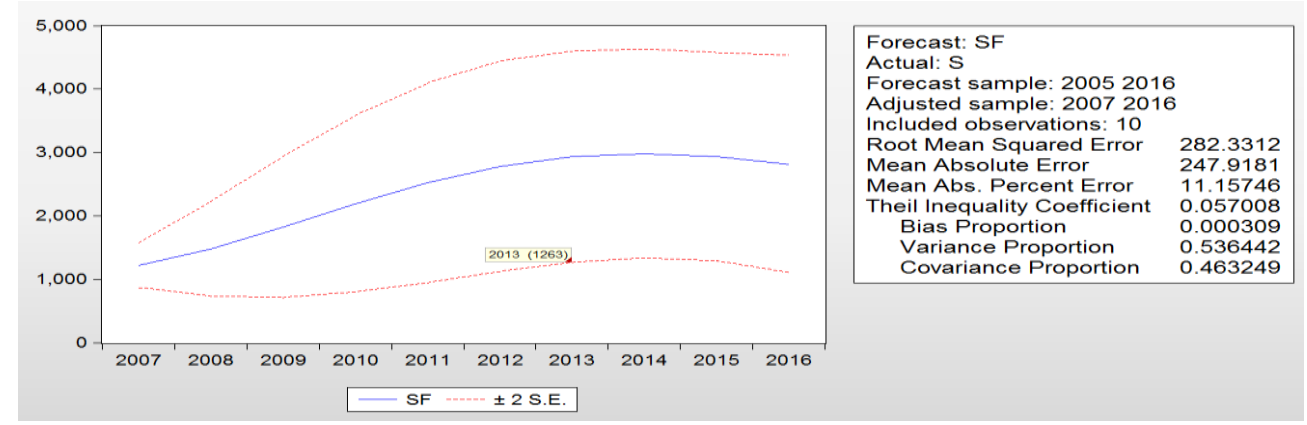

Tabel3.3Perbandingan Data Hasil Data Aktual dengan Hasil

Ramalan

\begin{tabular}{|c|c|c|}
\hline Tahun & Data Aktual & Data Ramalan \\
\hline 2005 & 1.192 & NA \\
\hline 2006 & 1.106 & NA \\
\hline 2007 & 1.183 & $1.216,656$ \\
\hline 2008 & 1.291 & $1.475,427$ \\
\hline 2009 & 1.525 & $1.820,398$ \\
\hline
\end{tabular}




\begin{tabular}{|l|l|l|}
\hline 2010 & 1.776 & $2.187,441$ \\
\hline 2011 & 2.230 & $2.519,848$ \\
\hline 2012 & 2.780 & $2.775,305$ \\
\hline 2013 & 3.258 & $2.929,621$ \\
\hline 2014 & 3.415 & $2.977,231$ \\
\hline 2015 & 3.183 & $2.928,911$ \\
\hline 2016 & 3.047 & $2.807,521$ \\
\hline
\end{tabular}

\section{Gambar3.15Grafik Residual Data Hasil Ramalan Pada Tahun 2007-} 2016

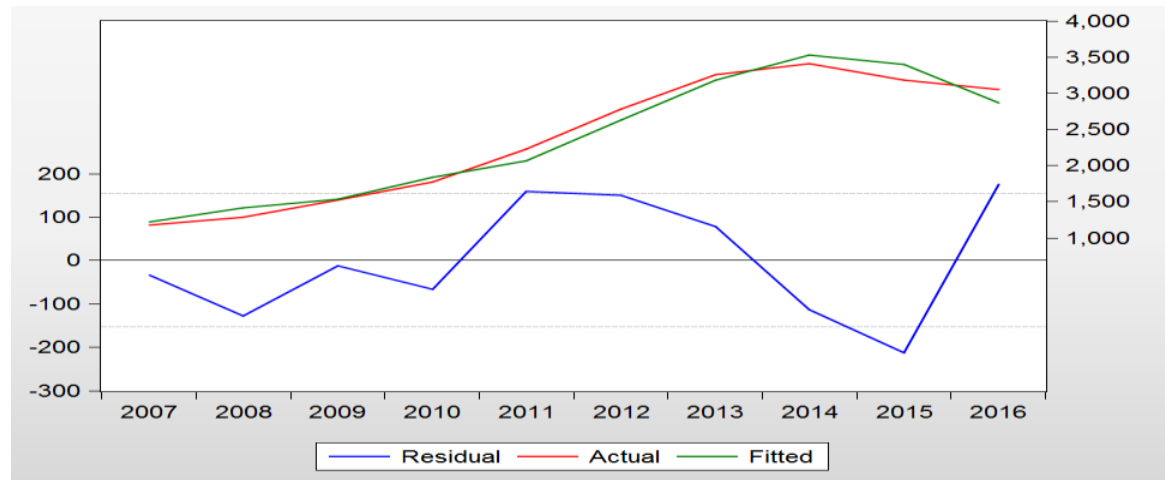

Berdasarkan hasil peramalan model ARMA $(2,0)$, untuk tahun 2005 dan 2006 tidak ada, ini berarti program EVIEWS menganalisis data dari 2007-2016. Pada tahun 2007, jumlah santri baru 1.183 dan hasil peramalannya sebesar $1.216,656$. Hal ini menunjukkan bahwa nilai ramalan sedikit lebih tinggi dibandingkan dengan nilai aktual, artinya diprediksikan pada tahun 2008 jumlah santri baru akan meneingkat dari jumlah santri sebelumnya. Berdasarkan data aktual tahun 2008, terbukti bahwa jumlah santri meningkat sebesar 1.108 daripada tahun 2007.

Peningkatan juga berlaku pada tahun-tahun berikutnya, berdasarkan data ramalan jumlah santri baru akan terus meningkat hingga pada tahun 2014, dan terbukti demikian. Pada tahun 2009 jumlah santri baru 1.525 (ramalan sebesar 1.820,398) dengan perbedaan data aktual dan ramalan sebesar 295,398, pada tahun 2010 jumlah santri baru 1.776 (ramalan sebesar 2.187,441) dengan perbedaan data aktual dan ramalan sebesar 411,441, pada tahun 2011 jumlah santri baru 2.230 (ramalan sebesar $2.519,848$ ) dengan perbedaan data aktual dan ramalan sebesar 289,848, dan pada tahun 2012 jumlah santri baru 2.780 (ramalan sebesar $2.775,305$ ) dengan perbedaan antara data aktual dan ramalan

$82 \mid$ JURNAL LISAN AL-HAL 
hanya 4,695. Kemudian, jumlah santri aktual pada tahun 2013 sebesar 3.258, sedangkan data ramalannya sebesar 2.929,621. Hal ini menunjukkan bahwa perbedaan antara data aktual dan ramalan sebesar 328,379. Selanjutnya, jumlah santri aktual pada tahun 2014 sebesar 3.415, sedangkan data ramalannya sebesar 2.977,231. Hal ini menunjukkan bahwa perbedaan antara data aktual dan ramalan sebesar 437,769. Sedangkan pada tahun 2015, jumlah santri aktual sebesar 3.183, sedangkan data ramalannya sebesar 2.928,911. Hal ini menunjukkan bahwa perbedaan antara data aktual dan ramalan sebesar 254,089. Sedangkan pada tahun 2016, jumlah santri aktual sebesar 3.047, yang mana data ramalannya sebesar 2.807,521. Hal ini menunjukkan bahwa perbedaan antara data aktual dan ramalan sebesar 239,479.

Berdasarkan data aktual dan ramalan pada tahun 2007-2016, juga diketahui bahwa data jumlah santri mengalami naik turun yang relatif besar. Misalnya, pada tahun 2014, jumlah santri naik sebesar 157 dari tahun 2013. Demikian juga pada data ramalannya, jumlah santri mengalami kenaikan sebesar 47,61, atau bila dibulatkan menjadi 48. Akan tetapi pada tahun 2015 sampai pada tahun 2016, jumlah santri baru mengalami penurunan yang relatif besar, dari jumlah 3.415 (2014) menjadi 3.183 (2015), dan 3.047 (2016). Bila dihitung keseluruhan, jumlah penurunan santri dari tahun 2015-2016 sebesar 368 orang santri. Berlaku juga pada data ramalannya, mengalami penurunan jumlah santri baru sebesar 169,71, atau bila dibulatkan menjadi 170 orang santri.

Tingkat penurunan jumlah santri, pada tahun 2015 sampai 2016 lebih dominan terjadi pada santri putri. Pada tahun 2014 santri putri berjumlah 1. 798.000, sedangkan santri putra berjumlah 1.617.000. Kemudian, pada tahun 2015 santri putri berjumlah 1.629.000, dan santri putra berjumlah 1.554. 000. Selanjutnya, pada tahun 2016 jumlah santri putri sebesar 1.542.000, dan jumlah santri putra sebesar 1.505.000.

Pendominasian penurunan yang sama juga terjadi pada tahun 2006, yang mana jumlah santri putri sebesar 555.000, sedangkan santri putra sebesar 551.000. Hal ini dilihat berdasarkan jumlah santri pada tahun 2005, yang mana santri putri berjumlah 644.000, dan santri putra berjumlah 548.000 .

Selanjutnya, berdasarkan data aktual dan ramalan pada tahun sebelumnya, akan dilakukan peramalan data untuk periode 5 tahun kedepan (tahun 2017, 2018, 2019, 2020,dan 2022) sebagai berikut:

Tabel3.4 Hasil Ramalan Pada Tahun 2017-2021

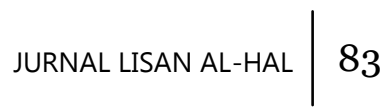




\begin{tabular}{|c|c|}
\hline Tahun & Data Ramalan \\
\hline 2017 & $2.642,701$ \\
\hline 2018 & $2.465,461$ \\
\hline 2019 & $2.303,476$ \\
\hline 2020 & $2.177,635$ \\
\hline 2021 & $2.100,145$ \\
\hline
\end{tabular}

Gambar 3.16Garfik Data Ramalan Pada Tahun 20172021

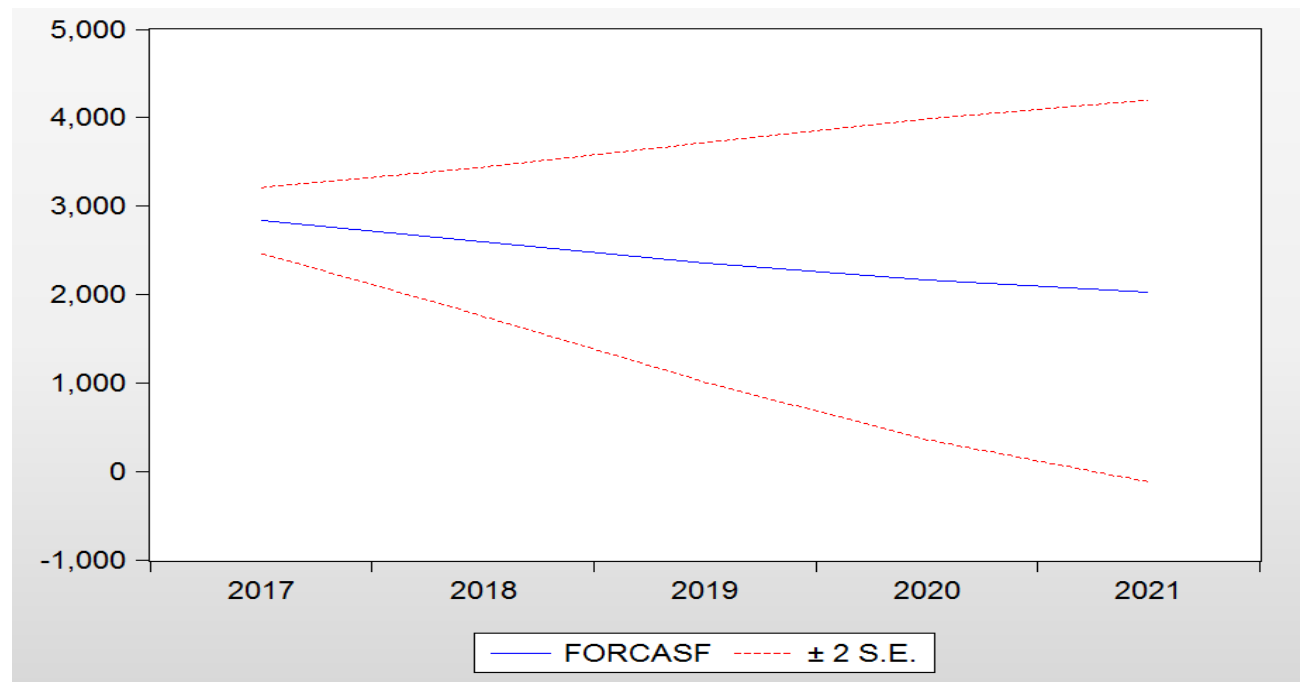

Berdasarkan tabel di atas, hasil peramalan (forcasting) 5 tahun masa mendatang santri baru Pondok Pesantren Salafiyah Syafi'iyah Sukorejo Situbondo terus mengalami penurunan yang drastis, yaitu pada tahu 2017 diperkirakan santri baru berjumlah 2.642,701, pada tahun 2018 berjumlah 2.465,461, pada tahun 2019 berjumlah 2.303,476, pada tahun 2020 berjumlah $2.177,635$, dan diprediksikan pada tahun 2021 berjumlah $2.100,145$. Nilai peramalan ini didasarkan pada data jumlah santri pada tahun-tahun sebelumnya yaitu pada tahun 2016, 2015, sampai tahun 2005, atau dari 2005-2016.

Meskipun nilai-nilai tersebut hanyalah bersifat prediksi, namun secara ilmiah memiliki kekuatan teoritis yang tinggi dibandingkan dengan nilai-nilai asumsi tanpa pendekatan ilmiah. Oleh karena itu, penting bagi pihak pesantren untuk melakukan suatu intropeksi berkait hal-hal yang menyebabkan menurunnya jumlah santri, yang berdasarkan data diketahui bahwa jumlah santri menurun drastis dimulai sejak tahun 2015 hingga tahun 2016. Periode sebelumnya yakni pada tahun 2014 jumlah

$84 \mid$ JURNAL LISAN AL-HAL 
santri sebesar 3.415.000, kemudian pada tahun 2015 jumlah santri sebesar 3.183.000, dan pada tahun 2016 jumlah santri sebesar 3.047.000. Meskipun pada tahun 2006 jumlah santri sebesar 1.106 .000 mengalami penurunan dari jumlah santri pada tahun 2005 yaitu sebesar1.192.000, namun tingkat penurunannya masih di bawah tingkat penurunan pada tahun 2015 sampai tahun 2016.

\section{Simpulan}

Berdasarkan ahasil analisis time seriesjumlah santri baru Pondok Pesantren Salafiyah Syafi'iyah Sukorejo Situbondo pada tahun 2005-2016 menggunakan model ARMA (p,q), maka dapat diketahui informasi bahwa model ARMA (p,q) merupakan salah satu model analisis data time series. Proses pemodelan dapat menggunakan metode Box-Jenkins yang terdiri dari: tahap identifikasi, tahap estimasi parameter model, tahapuji diagnosis, dan tahap peramalan.Selanjutnya, berdasarkan langkah-langkah model ARMA, diperoleh model persamaan sebagai berikut:

\section{Data $_{t}=2.368,067+1,689962$ data $_{t-1}-0,834506$ data $_{t-2}+e_{t}$}

Hasil peramalan jumlah santri baru Pondok Pesantren Salafiyah Syafi'iyahSukorejo Situbondo pada 5 tahun masa mendatang, yaitu pada tahun 2017 (jumlah ramalan sebesar 2.642,701), pada tahun 2018 (jumlah ramalan sebesar 2.465,461), pada tahun 2019 (jumlah ramalan sebesar 2.303,476), pada tahun 2020 (jumlah ramalan sebesar 2. 177, 635), dan pada tahun 2021 (jumlah ramalan sebesar 2.100,145).

Tingkat kenaikan jumlah santri dimulai pada tahun 2007 hingga pada tahun 20014, kemudian baru mengalami penurunan pada tahun 2015 dan 2016. Penurunan jumlah santri didominasi oleh santri putri, sedangkan penurunan pada santri putra bersifat resesif. Pendominasian penurunan jumlah santri oleh putri juga pernah terjadi pada tahun 2005 dan 2006.

\section{DAFTAR PUSTAKA}

Anam, C. (ed.). KHR. As'ad Syamsul Arifin: Riwayat Hidup dan Perjuangannya, Situbondo: Pondok Pesantren Salafiyah Safiiyah Sukorejo. 1994.

Arikunto. Prosedur Penelitian. Yogyakarta: Rineka Cipta. 2014.

Hari Santosa, S. Disparitas Pertumbuhan Ekonomi dan Pembangunan Ekonomi Wilayah Di Satuan Wilayah Pembangunan IV Provinsi Jawa Timur. Jurnal ilmiah Universitas Jember, Media Trend Vol.,10 No.2. 
2015.

Nogroho, A, dkk. Model ARMA (Autoregressive Moving Average) untuk Memprediksi Curah Hujan di Kabupaten Semarang Jawa Tengah Indonesia. Jurnalilmiah Universitas Kristen Satya Wacana. Diakses pada pukul: 22.45 WIB.01 Desember 2016.

Sugiono. Statistika untuk Penelitian. Bandung: Alfabeta. 2015.

Sumanto. Statistika Terapan. Yogyakarta: CAPS. 2014.

Wahyu Winarno,W. Analisis Ekonomitrika dan Statistika dengan Eviews. Yogyakarta: UPP STIM YKPN. 2015.

Walpole,R.E dan Raymon H,M. Ilmu Peluang dan Statistika untuk Insyinyur dan Ilmuwan. Bandung: ITB. 1995.

Widarjono, A. Ekonomitrika: Pengantar dan Aplikasinya. Yogyakarta: UPP STIM YKPN. 2016.

86 JURNAL LISAN AL-HAL 